\title{
HYBRYDOWE PRAWNE FORMY DZIAŁANIA W ADMINISTRACJI PUBLICZNEJ
}

\begin{abstract}
WSTĘP
Obecnie zauważyć można coraz bardziej zacierającą się granicę pomiędzy prawem administracyjnym a prawem cywilnym $\mathrm{w}$ odniesieniu do prawnych form stosowanych $\mathrm{w}$ administracji publicznej. To zjawisko przyczyniło się do zgłębienia problematyki, która mogłoby się wydawać, że nie stanowi (może nie stanowić) aż tak daleko idących ingerencji w prawo administracyjne, a co za tym idzie - nie wywołuje w tak dużym stopniu występowania i posługiwania się przez organy administracji publicznej hybrydowymi prawnymi formami.

Zagadnienie prawnych form działania w administracji publicznej stanowi temat wielu publikacji także współczesnych nauk: prawa administracyjnego i o administracji. Nie zmienia to jednak faktu, że do tej pory nie określono jednego, spójnego katalogu prawnych form działania, ich typologii oraz sposobu ich klasyfikacji. Przede wszystkim dlatego (i należy uznać to za w pełni zasadne), że współczesna administracja publiczna realizuje zadania publiczne, które wymuszają na ustawodawcy dostosowanie do nich odpowiednich form

Dr Paulina Bieś-Srokosz - adiunkt, Katedra Prawa Administracyjnego i Finansowego, Wydział Prawa i Ekonomii na Uniwersytecie Humanistyczno-Przyrodniczym im. Jana Długosza w Częstochowie, ul. Zbierskiego 2/4, 42-200 Częstochowa; e-mail: p.bies@ujd.edu.pl; https:// orcid.org/0000-0002-7353-3460.

Dr PrzemysŁaw NiemczuK - adiunkt, Katedra Prawa Publicznego, Zakład Prawa Administracyjnego i Nauki Administracji w WSPiA Rzeszowskiej Szkole Wyższej; ul. Cegielniana 14, 35-310 Rzeszów; e-mail: pnieczuk@wspia.eu; ORCID: https://orcid.org/0000-0002-2274-0128.
\end{abstract}


prawnych, które na przestrzeni ostatnich dwóch dekad posiadają wiele cech prywatnoprawnych.

Można zauważyć pewnego rodzaju tendencje w działaniu ustawodawcy. Formami o charakterze publicznoprawnym posługuje się wtedy, kiedy jest możliwe zastosowanie władczości administracji, uregulowanie jednostronnych stosunków stron. Natomiast tam, gdzie zadanie publiczne wymusza „łagodniejsze" prawne formy działania administracji, dwustronność stron, wtedy prawodawca sięga po prawne formy o charakterze prywatnoprawnym ${ }^{1}$ bądź dokonuje modyfikacji prawnych form o charakterze prywatnoprawnym dodając elementy publicznoprawne, tworząc tym samym hybrydowe formy prawne ${ }^{2}$.

\section{PRAWNE FORMY DZIALANIA ADMINISTRACJI PUBLICZNEJ W DOKTRYNIE VS DZIAŁALNOŚĆ PRAWODAWCZA USTAWODAWCY}

Doktryny: nauki administracji i prawa administracyjnego aktualnie borykają się z brakiem jednolitego katalogu prawnych form działania w administracji publicznej ${ }^{3}$. Przyczyn takiego stanu należy upatrywać przede wszystkim w niekonsekwencji działań ustawodawcy. Wyrażamy przekonanie, że można mówić o pewnego rodzaju trendzie kopiowania instytucji prawnych $\mathrm{z}$ jednej gałęzi prawa do innej. W tym przypadku mowa tutaj o powielaniu rozwiązań prawnych z prawa prywatnego do prawa publicznego (prawa administracyjnego). Można odnieść wrażenie, że prawodawca chce „na siłę” przenieść prywatnoprawne instytucje prawne do prawa publicznego. Takie działanie nie jest $\mathrm{w}$ pełni uzasadnione, ponieważ powoli zaciera się granica między tymi dwiema gałęziami prawa, a funkcjonujące $w$ obrocie prawnym

\footnotetext{
${ }^{1}$ Umowa cywilnoprawna, która stanowi jedną z form działania administracji publicznej, nie przybiera swojej „czystej formy” wynikającej z postanowień kodeksowych. Co więcej, jest ona obwarowana dodatkowymi warunkami, które musi spełnić kontrahent, aby mogła funkcjonować w obrocie prawnym. Stosowanie tej formy w administracji publicznej ma co do zasady przynieść możliwość optymalnego kształtowania wzajemnych praw i obowiązków czy też bezpośredniej kontroli wykonywania zaciągniętych zobowiązań. Zob. J. LEMAŃSKA, Umowa administracyjna a umowa cywilnoprawna, [w:] Instytucje wspótczesnego prawa administracyjnego, red. I. Skrzydło-Niżnik, P. Dobosz, D. Dąbek, M. Smaga, Kraków: Wydawnictwo Uniwersytetu Jagiellońskiego 2001, s. 422.

${ }^{2}$ P. BIEŚ-SRokosz, Nowe formy organizacyjno-prawne warunkiem dobrego administrowania?, [w:] Aksjologia prawa administracyjnego, red. J. Zimmermann, Warszawa: Wydawnictwo Wolters Kluwers 2017, s. 307-316.

${ }^{3}$ Zob. więcej o prawnych formach administracji publicznej w: I. LIPOwICZ, Prawne formy działania administracji publicznej - między stabilizacja a potrzeba przetomu, „Ruch Prawniczy, Ekonomiczny i Socjologiczny” 2016, nr 4, s. 44-51.
} 
instytucje prawne mają cechy publicznoprawne i prywatnoprawne. Przykładem mogą być coraz częściej popularne zjawiska prywatyzacji prawa publicznego oraz publicyzacji prawa prywatnego. Choć tematyka ta nie stanowi głównej problematyki artykułu, to warto zaznaczyć, że odgrywają znaczącą rolę w realizacji form zadań publicznych.

Proces publicyzacji prawa prywatnego niewątpliwie nasilił się w związku z coraz większą jurydyzacją życia społecznego oraz przekonaniem o możliwości uregulowania wielu aspektów życia jednostki. Skutkiem tego jest odchodzenie od procesu spontanicznego kształtowania się norm postępowania w relacjach międzyludzkich, które przez L. Fullera zostały określone jako interactional law. Szczególnie widoczne jest to w prawie prywatnym, które w swoim klasycznym ujęciu właściwie całkowicie było tworzone w ramach swobody jednostki i autonomii woli stron. Wydaje się, że tendencja ta będzie narastać, pomimo wielokrotnych postulatów „deregulacji” podnoszonych przez zwolenników liberalizmu gospodarczego ${ }^{4}$.

Proces publicyzacji prawa prywatnego ${ }^{5}$ nie musi jednak oznaczać automatycznego przejścia do metody zarządzania wybranymi odcinkami życia społecznego opartej na tradycyjnie rozumianym władztwie państwa. Raczej należałoby się spodziewać powstawania form mieszanych, łączących w sobie elementy metody publicznoprawnej z elementami prywatnoprawnymi. W takim kontekście, w szczególności w zakresie prawa administracyjnego, w literaturze często pojawia się określenie „prywatyzacja prawa publicznego”, rozumiane jako odchodzenie przez państwo od metod typowo władczych w kierunku stosowania metod charakterystycznych dla prawa prywatnego. Należy jednak zauważyć, że takie przemiany dotyczą przede wszystkim obszarów zawłaszczanych przez regulację państwa, dotychczas od niej wolnych, gdzie

\footnotetext{
${ }^{4} \mathrm{~J}$. SROKOSZ, Juridification of social life and proces of private law publicisation, [w:] Mutual interaction between contemporary systems and branches of law in European Countries, red. P. Bieś-Srokosz, J. Srokosz, E. Żelasko-Makowska, Częstochowa: Wydawnictwo S. Podobińskiego 2017, s. 166-167.

${ }^{5}$ Według M. Safjana proces publicyzacji prawa prywatnego widoczny jest przede wszystkim w czterech zjawiskach w życiu społecznym: władczej ingerencji państwa w obszary zarezerwowane dotychczas dla regulacji przez strony stosunków prawnych, wypieraniu metody prywatnoprawnej przez metodę publicznoprawną w zakresie stosunków w ramach prawa prywatnego, coraz częstsze promowanie interesu społecznego kosztem interesu indywidualnego oraz w coraz większym rozproszenie regulacji prawnych odnoszących się do partykularnych wycinków życia społecznego. M. Safuan, Pojęcie i systematyka prawa prywatnego, [w:] System prawa prywatnego, t. I: Prawo cywilne - część ogólna, red. M. Safjan, Warszawa: Wydawnictwo C.H. Beck 2007, s. 48.
} 
podstawową rolę odgrywała wola stron stosunków prawnych. W mniejszym stopniu dotyczy to zmiany charakteru tradycyjnych dziedzin regulowanych przez prawo publiczne, choć i takie niewątpliwie się zdarzają. Publicyzacja prawa prywatnego oznacza zatem przyjmowanie różnych form i zakres ingerencji państwa $\mathrm{w}$ relacje prywatnoprawne, co prowadzi do stopniowego poddawania regulacji kolejnych obszarów życia społecznego, a więc rozszerzania się procesu jurydyzacji.

Konsekwencją powyżej wskazanych działań ustawodawcy jest zmiana prawnych form realizacji zadań publicznych $w$ administracji, przez co coraz częściej zadania publiczne są wykonywane przez podmioty prywatne. A to z kolei stanowi odwrotność publicyzacji prawa prywatnego, tworząc (kształtując) zjawisko prywatyzacji prawa publicznego ${ }^{6}$. Zjawisko to określane jest jako ucieczka państwa $\mathrm{z}$ dziedziny prawa publicznego $\mathrm{w}$ sferę prywatnoprawną i przenoszenie zadań publicznych na przedsiębiorstwa lub korporacje ${ }^{7}$. Zdaniem T. Rabskiej ${ }^{8}$, prywatyzacja zadań publicznych ${ }^{9}$ polega na kurczeniu się aparatu administracji publicznej oraz na wyprowadzeniu określonego zadania (lub jego części) ze struktur administracyjnych ${ }^{10}$. Prywatyzację zadań publicznych można postrzegać jako twórczy proces w zakresie sposobu wykonywania zadań publicznych przez podmioty niepubliczne, które przejmują je w sposób dobrowolny, prowadząc je w interesie ogólnym, a nie jednostkowym ${ }^{11}$. W konsekwencji przez prywatyzację należy rozumieć przejmowanie wykonywania zadań publicznych należących do państwa przez podmioty niepubliczne, z jednoczesnym przekształceniem własności publicznej we własność prywatną ${ }^{12}$.

Zasadniczymi impulsami do prywatyzacji zadań publicznych we współczesnych systemach prawnych stały się procesy globalizacji gospodarki,

${ }^{6}$ J. Helios, Publicyzacja prawa prywatnego - prywatyzacja prawa publicznego $w$ kontekście rozważań nad prawem europejskim, „Przegląd Prawa Administracyjnego” 92(2013), nr 3502, s. 27.

${ }^{7}$ A. ŻURAwIK, Problem publicyzacji prawa prywatnego w kontekście ustrojowym, „Państwo i Prawo" 65 (2010), nr 5, s. 39.

${ }^{8}$ T. RABSKA, Możliwości zmian ustawy samorzadowej, „Samorząd Terytorialny” 1994, nr 10, s. 14.

${ }^{9} \mathrm{O}$ prywatyzacji zadań publicznych szerzej w: J.M. CwALIŃSKA, Prywatyzacja zadań publicznych - przyczynek do dyskusji, ,Przegląd Prawa Publicznego” 2020, nr 3, s. 24-37.

${ }^{10}$ Przykład mogą stanowić szkoły prywatne czy też szpitale prywatne.

${ }^{11}$ L. ZACHARKO, Prywatyzacja zadań publicznych gminy: studium administracyjnoprawne, Katowice: Wydawnictwo Uniwersytetu Śląskiego 2000, s. 32.

${ }^{12}$ Podobne stanowisko rozumienia prywatyzacji w ramach koncepcji anglosaskich prezentuje A. BŁAś, Współczesne tendencje przeobrażeń zadań administracji publicznej, [w:] Administracja publiczna, red. A. Błaś, J. Boć, J. Jeżewski, Wrocław: Wydawnictwo Kolonia Limited 2003, s. 148. 
swoboda przepływu dóbr, usług, ludzi i kapitału ${ }^{13}$. Państwo we współczesnym świecie zmienia swą funkcję, stąd też zdaniem W. Szostaka należy się spodziewać przede wszystkim zmiany „celów i zadań państwa, z czym wiąże się zmiana zakresu władzy państwowej, a pośrednio ciężaru państwa"14. Niemniej jednak, według S. Zawadzkiego,

redukcja zadań publicznych nie powinna zaskakiwać obywateli, gdyż grozi to powstaniem poważnych konfliktów społecznych. W świetle zmian zachodzących globalnie rozsądna i możliwa do przyjęcia wydaje się koncepcja państwa o orientacji społecznej. Państwo, poza tradycyjnymi zadaniami ochrony bezpieczeństwa zewnętrznego i wewnętrznego, prowadzić powinno aktywną politykę społeczną, która obejmuje pomoc na rzecz osób biednych i upośledzonych, dążenie do eliminacji niesprawiedliwości społecznej, zapewnienie jednostce równych szans w dążeniu do awansu społecznego (głównie przez rozwój edukacji i jej szerokie udostępnienie), skuteczne łagodzenie sprzeczności społecznych i zmniejszanie różnic w podziale dochodu narodowego między biednych i bogatych ${ }^{15}$.

Prywatyzacja zadań publicznych uwidacznia się w zakresie zmiany stosunków własnościowych i obejmuje proces przeniesienia praw właścicielskich (zarówno w znaczeniu prawnym, jak i ekonomicznym) z podmiotu publicznego na rzecz podmiotu prywatnego ${ }^{16}$. Zdaniem S. Biernata, pojęcie prywatyzacji zadań publicznych nie ma ustalonego znaczenia ani w polskim prawie, ani w literaturze ${ }^{17}$. Dlatego też należy rozumieć je jako „wszelkie przejawy odstępowania od wykonywania zadań przez podmioty administracji publicznej, działające w formach prawa publicznego" 18 . S. Biernat proponuje posługiwanie się pojęciem prywatyzacji zadań publicznych w szerokim jego rozumieniu, ze względu na to, że jego określenie odnosi się między innymi do przejmowania zadań publicznych przez różnorodne podmioty niebędące organami (zakładami) państwowymi lub samorządem terytorialnym. Według

${ }^{13}$ A. BŁAŚ, Granice prywatyzacji zadań publicznych w państwie prawa, [w:] Samorząd terytorialny III Rzeczypospolitej. 10 lat doświadczeń, red. S. Michałowski, Lublin: Wydawnictwo UMCS, s. 304.

${ }^{14}$ W. Szostak, Problem , ciężaru państwa”, Kraków: Wydawnictwo Księgarnia Akademicka 1998, s. 241.

${ }^{15}$ S. ZAWADZKI, Państwo o orientacji społecznej, Warszawa: Wydawnictwo Naukowe Scholar 1996, s. 178.

${ }^{16}$ S.T. SuRDYKOwSKA, Prywatyzacja, Warszawa: Wydawnictwo Naukowe PWN 1996, s. 137 n.

${ }^{17}$ S. Biernat, Prywatyzacja zadań publicznych. Problematyka prawna, Warszawa: Wydawnictwo Naukowe PWN 1994, s. 25.

18 Tamże. 
autora, za szeroko rozumianym pojęciem prywatyzacji zadań publicznych przemawia wiele argumentów. „Po pierwsze, jak wykazuje analiza rozwiązań przyjętych $\mathrm{w}$ obowiązującym porządku prawnym, te same zadania publiczne mogą być przekazywane szerokiemu i zróżnicowanemu kręgowi podmiotów, np. kościołom, organizacjom społecznym, podmiotom gospodarczym lub osobom fizycznym" ${ }^{19}$. Po drugie, zdaniem S. Biernata, przyczyny, dla których dokonuje się przekazywania zadań należących do organów publicznych, są w gruncie rzeczy podobne, bez względu na charakter podmiotów przejmujących te zadania.

Jaki zatem jest typowy katalog prawnych form działania administracji publicznej? Najczęściej wyróżnia się katalog ustalony przez J. Starościaka ${ }^{20}$, tj.: stanowienie przepisów powszechnie obowiązujących, wydawanie aktów administracyjnych, zawieranie umów, zawieranie porozumień administracyjnych, prowadzenie działalności społeczno-organizatorskiej, wykonywanie czynności materialno-technicznych. Należy podkreślić, że powyższa grupa prawnych form działania występuje w stosunkach zewnętrznych administracji. W przypadku wystąpienia stosunków wewnętrznych nie będziemy mieć do czynienia z zawieraniem porozumień, ugód i umów, a stanowienie przepisów prawnych powszechnie obowiązujących i wydawanie aktów administracyjnych przybierze postać polecenia służbowego ${ }^{21}$.

Warto jednak zaznaczyć, że współczesne prawne formy działania administracji podlegają procesowi ciągłej ewolucji. Pojawiają się również nowe instrumenty prawne, które nie mieszczą się w ukształtowanej przez doktrynę siatce pojęciowej ${ }^{22}$. Administracja publiczna jest w ciągłym procesie rozwoju, stąd też potrzebna jest jej stała aktualizacja istniejących form bądź wręcz poszukiwanie nowych prawnych form działania, które odpowiadają jej aktualnym potrzebom. Jednakże należy podkreślić, że nie chodzi tutaj o sztuczne tworzenie nowych instrumentów prawnych, ale o uporządkowanie dotychczasowych i dostosowanie ich do zmieniającej się administracji publicznej oraz jej coraz szerszej współpracy z podmiotami niepublicznymi ${ }^{23}$.

\footnotetext{
${ }^{19}$ Tamże, s. 32.

${ }^{20}$ J. StARoŚCIAK, Prawne formy i metody działania administracji, [w:] System prawa administracyjnego, red. T. Rabska, J. Łętowski, t. III, Warszawa-Wrocław-Kraków-Gdańsk: Wydawnictwo Zakład Narodowy im. Ossolińskich 1978, s. 45.

${ }^{21}$ Zob. tamże.

22 B. DOlNiCKI, R. CYBULSKA, Nowe dwustronne formy działania administracji publicznej. Zagadnienia wybrane, [w:] Koncepcja systemu prawa administracyjnego. Zjazd Katedr Prawa Administracyjnego i Postępowania Administracyjnego, Zakopane 24-27 września 2006 r., red. J. Zimmermann, Warszawa: Wydawnictwo Oficyna 2007, s. 471.

${ }^{23}$ Tamże, s. 472.
} 
Problem związany z klasyfikacją konkretnych prawnych form działania administracji publicznej wiąże się także ze zmianą podmiotów realizujących zadania publiczne. Chodzi przede wszystkim o zwiększenie udziału podmiotów niepublicznych w wykonywaniu zadań publicznych, które odbywa się w ramach przeprowadzonych przetargów publicznych (działalności pożytku publicznego czy w ramach partnerstwa publiczno-prywatnego) bądź wprost na podstawie przepisów prawa. Podmioty niepubliczne tworzą katalog podmiotów, które wykonują zadania publiczne, pozostając na zewnątrz administracji publicznej, niezależnie od ich statusu prawnego czy też rodzaju wykonywanych zadań, a także związanych z nimi kompetencjami i sposobem powierzania im tych zadań ${ }^{24}$. Przepisy ustawowe wskazują wprost, który niepubliczny podmiot może zrealizować zadanie publiczne oraz w jakiej prawnej formie. Mogą to być zarówno podmioty sektora komercyjnego, jak i o charakterze non-profit. Powierzanie (zlecanie, przekazywanie) zadań publicznych może nastąpić albo bezpośrednio w samej ustawie, albo w drodze umowy/porozumienia, których zawarcie wymaga ustawowej podstawy prawnej. Fakt realizacji zadania publicznego przez podmiot niepubliczny, w ramach zlecenia, nie przyczynia się ani do zmiany charakteru prawnego tego zadania, ani do zmiany statusu prawnego tego podmiotu. Można jednak przy tym mówić o dodatkowych obowiązkach lub uprawnieniach takiego podmiotu ściśle związanych z realizowanym zadaniem publicznym.

Według M. Stefaniuka ${ }^{25}$, uzasadnieniem dla powierzania nietypowym podmiotom $^{26}$ zadań administracji publicznej jest m.in.: wzrost dynamiki życia społecznego, procesy „integracji wertykalnej” administrowania w wymiarze międzynarodowym, ujawnianie się nowych dziedzin aktywności państwa i symptomy kryzysu tradycyjnych struktur aparatu administracyjnego. Należy zaznaczyć, że zadania przypisywane konkretnym podmiotom i ich organom w ustawach ustrojowych często są określane w sposób ogólny. Jednak na wykonanie danego zadania składają się jeszcze cząstkowe działania, których określenie co do formy, zakresu i podmiotu wymaga głębszej analizy przepisów

${ }^{24}$ P. WILCZYŃSKI, Podmioty niepubliczne w sferze administracji publicznej, „Państwo i Prawo” 2002, nr 2, s. 56-57.

${ }^{25}$ M. STEFAnIUK, Działanie administracji publicznej w ujęciu nauk administracyjnych, Lublin: Wydawnictwo Uniwersytetu Marie Curie-Skłodowskiej 2009, s. $141 \mathrm{n}$.

${ }^{26}$ Nietypowe podmioty $\mathrm{w}$ administracji publicznej należą do grupy podmiotów cechujących posiadanie osobowości prawnej, wykonywanie zadań publicznych o specyficznym zakresie przedmiotowym i korzystanie w dominującej mierze z prywatnoprawnych form działania. 
ustrojowych oraz materialnych. Jak stwierdza M. Stahl ${ }^{27}$, wiele organów, wykonujących zadania publiczne, ma nietypowy status prawny. Obok samorządu terytorialnego zadania administracji publicznej wykonują również inne organy, niezależne od administracji, o wąskim i wyspecjalizowanym zakresie.

\section{PRAWNE FORMY DZIAŁANIA O CHARAKTERZE HYBRYDOWYM}

Prawne formy działania o charakterze hybrydowym stanowią swoistego rodzaju grupę prawnych form, która odróżnia się od pozostałych przede wszystkim zróżnicowanymi cechami, właściwymi zarówno dla prawa publicznego, jak i prawa prywatnego. Grupa ta jest na tyle niejednorodna, że nie można stworzyć ich katalogu ze względu na łączące je cechy. Jedynym punktem wspólnym odniesienia jest fakt, że prawne formy prawa publicznego posiadają cechy prawa prywatnego, zaś prawne formy prawa prywatnego - cechy prawa publicznego. Mieszany charakter prawny w odniesieniu do prawnych form o charakterze publicznym przyczynia się do sporu w doktrynie prawa administracyjnego co do właściwej klasyfikacji konkretnej już formy prawnej. Częstym przedmiotem tychże sporów stają się umowy w administracji publicznej. Choć wiadome jest, że działanie administracji publicznej opiera się na kształtowaniu stosunków (zależności) na podstawie aktów prawnych, to coraz częściej to prawo dopuszcza do uzupełniania regulacji prawnych wykorzystując umowy ${ }^{28}$. Wielość umów i ich różnorodność w administracji publicznej przyczynia się do tego, że nigdy nie będziemy mieć pewności na „pierwszy rzut oka”, z jakim rodzajem umowy mamy do czynienia. Dlatego też ważne jest przeanalizowanie, czy umowa jest zawierana $\mathrm{z}$ podmiotem będącym $\mathrm{w}$ strukturze administracji publicznej czy poza nią; czy postanowienia umowne bezpośrednio czy pośrednio dotyczą kwestii związanych $\mathrm{z}$ organizowaniem wykonywania administracji publicznej; czy przedmiot umowy ma charakter publicznoprawny czy prywatnoprawny. Niestety, umowy jako dwustronne prawne formy działania administracji publicznej są wprowadzane przez ustawodawcę do prawa administracyjnego bardzo chaotycznie i sporadycznie, brakuje również opracowań naukowych

\footnotetext{
${ }^{27}$ M. STAHL, Zagadnienia ogólne, [w:] Podmioty administrujace. System prawa administracyjnego, red. R. Hauser, A. Wróbel, t. VI, Warszawa: Wydawnictwo C.H. Beck 2011, s. 40.

${ }^{28}$ Zob. P. LISOwSKI, Ustrojowe konsekwencje umów w administracji. Wybrane zagadnienia, [w:] Umowy w administracji, red. J. Boć, L. Dziewięcka-Bokun, Wrocław: Wydawnictwo Kolonia Limited 2008, s. 89.
} 
związanych $\mathrm{z}$ tą tematyką ${ }^{29}$. Jednym $\mathrm{z}$ najczęściej przywoływanym przykładem dwustronnych prawnych form działania, powodującym problemy w prawidłowej klasyfikacji tej formy, jest umowa administracyjna. Przeważnie jest ona mylona $z$ umową cywilnoprawną, ponieważ jej zakres przedmiotowy dotyczy określenia uprawnień lub obowiązków jednostki jej zawierającej. Podstawowym kryterium, które pozwala na stwierdzenie, że mamy do czynienia z umową administracyjną, jest charakter świadczeń przewidzianych umową. Świadczenia te mogą być dokonane tylko przez organ dysponujący cząstką władzy publicznej i są one przejawem jej sprawowania ${ }^{30}$.

Kolejnym przykładem hybrydowej prawnej formy działania jest kontrakt socjalny, który w doktrynie prawa administracyjnego często uznaje się za formę o charakterze prywatnoprawnym. Zgodnie $\mathrm{z}$ art. 108 ustawy o pomocy społecznej ${ }^{31}$, aby określić sposób współdziałania w rozwiązywaniu problemów osoby lub rodziny znajdujących się w trudnej sytuacji życiowej, pracownik socjalny zatrudniony w ośrodku pomocy społecznej lub w powiatowym centrum pomocy rodzinie może zawrzeć kontrakt socjalny z tą osobą lub rodziną, w celu wzmocnienia aktywności i samodzielności życiowej, zawodowej lub przeciwdziałania wykluczeniu społecznemu. Treść kontraktu ustala zasady współdziałania podmiotu administracji wraz ze stroną w przedmiocie rozwiązywania jej ciężkiej sytuacji. Z kolei strony kontraktu ustalają wspólne obowiązki oraz prawa, warunkując je od typu pomocy społecznej. Podmiot administracji zobowiązany jest do udzielenia pewnego rodzaju pomocy, natomiast osoba, która ubiega się o tę pomoc, wyraża chęć współdziałania, mając przy tym świadomość, że pomoc taka zostanie jej udzielona pod warunkiem wywiązania się z postanowień kontraktu ${ }^{32}$.

Co do zasadności funkcjonowania w obrocie prawnym kontraktu socjalnego należy podkreślić, że jest oceniany bardzo pozytywnie zarówno przez osoby pracujące $w$ systemie pomocy socjalnej, jak i przez samych korzystających z pomocy w ramach tego kontraktu.

${ }^{29}$ J. Zimmermann, Prawo administracyjne, Kraków: Wydawnictwo Zakamycze 2005, s. 398.

${ }^{30}$ D. KiJowski, Umowy w administracji publicznej, [w:] Podmioty administracji publicznej i prawne formy ich działania. Studia i materiaty z konferencji jubileuszowej Profesora Ochendowskiego, Toruń: Wydawnictwo Dom Organizatora TNOiK 2005, s. 297.

${ }^{31}$ Ustawa z dnia 12 marca 2004 r. o pomocy społecznej, t.j. Dz.U. z 2020 r., poz. 1876, 2369.

32 J. WYPORSKA-FRANKIEWICZ, Publicznoprawne formy działania administracji o charakterze dwustronnym, Warszawa: Wydawnictwo Wolters Kluwer 2010, s. 268. 
Kontrakt socjalny bez wątpliwości stanowi prawną formę dwustronną działania administracji. Treści kontraktu nie ustala organ administracji publicznej, ale uzgadniają je obie strony. Kontrakt bardzo przypomina umowę cywilnoprawną, niemniej nie ma podstaw prawnych, aby uznać go za taką postać prawną. Pomimo tego, że wielu przedstawicieli doktryny toczy spór o jego klasyfikację, to naszym zdaniem mamy do czynienia z przykładem hybrydowej prawnej formy działania w administracji publicznej. Mianowicie jest to dwustronna forma działania, która może być podjęta na warunkach ustalonych przez strony. Stąd też możemy mówić o pewnego rodzaju swobodzie stron, która powinna powodować szybszą i bardziej ekonomiczną pracę pracowników pomocy społecznej. Jednakże ta konstrukcja prawna nie jest pozbawiona wad. Do nich należy przede wszystkim fakt, że - po pierwsze - nie ma jasno określonych skutków prawnych niedotrzymania postanowień kontraktu ze strony pracownika socjalnego; po drugie - nie ma określonych terminów czasowych związania takim kontraktem.

Innym przykładem może być ugoda wodnoprawna jako szczególna konsensualna forma działania administracji. Przyjąć przy tym należy, że różni się ona od ugody administracyjnej; są to dwie odmienne prawne formy działania administracji, wykazujące się swoją specyfiką, oparte na innych przepisach zarówno o charakterze procesowym, jak i materialnym. Dodać trzeba, że problematyka konsensualnego kształtowania stanu wody na gruncie może następować w dwóch rodzajach ugód: ugody wodnoprawnej zatwierdzanej na podstawie art. 235 Prawa wodnego ${ }^{33}$, oraz ugody administracyjnej zatwierdzanej na zasadach określonych $\mathrm{w}$ rozdziale 8 k.p.a. ${ }^{34} \mathrm{w}$ postępowaniu prowadzonym w trybie art. 234 ust. 3 Prawa wodnego. W odniesieniu do obu ugód można przyjąć wspólną cechę, mianowicie nie powinny zakłócać korzystania $\mathrm{z}$ wód $\mathrm{w}$ świetle art. 234 Prawa wodnego ${ }^{35}$. Dotyczy to zarówno gruntów objętych ugodą, jak i gruntów sąsiednich niebiorących udziału $\mathrm{W}$ zawarciu ugody ${ }^{36}$. Z formalnego punktu widzenia pozostają to jednak dwie różne prawne formy działania. Ugoda wodnoprawna, w przeciwieństwie do ugody administracyjnej, stanowi samoistną formę prawną. Postępowanie wszczęte w tym trybie ma na celu zawarcie takiej ugody. Ugoda wodno-

\footnotetext{
${ }^{33}$ Ustawa z dnia 20 lipca 2017 r. - Prawo wodne, Dz.U. z 2020 r., poz. 310.

${ }^{34}$ Ustawa z dnia 14 czerwca 1960 r. - Kodeks postępowania administracyjnego, Dz.U. z 2020 r., poz. 256 [dalej: k.p.a.].

${ }^{35}$ Por. np. M. KAŁUŻNY, Prawo wodne. Komentarz, Warszawa: Wydawnictwo Wolters Kluwer 2016, s. 163.

${ }^{36}$ Zob. np. J. SzachuŁowicz, Prawo wodne. Komentarz, Warszawa: Wydawnictwo Wolters Kluwer 2010, s. 121.
} 
prawna jest więc celem postępowania, a nie alternatywną formą załatwienia sprawy - jak ugoda administracyjna.

W postępowaniu prowadzonym w trybie art. 235 Prawa wodnego występują dwa etapy: cywilnoprawny i administracyjnoprawny. Pierwszy kończy się zawarciem ugody przez zainteresowanych właścicieli gruntów. Podstawową przesłanką jej zawarcia jest konsensus w przedmiocie kształtu stanu wody na gruntach nią objętych. Nie jest to jednak wyłączna przesłanka. Drugą przesłanką jest brak szkodliwego oddziaływania uzgodnionych rozwiązań na inne nieruchomości lub na gospodarkę wodną, czyli na jakikolwiek grunt pozostający pod wpływem oddziaływania przekształcenia stanu wody wywołanego ugodą, niezależnie od jego oddalenia. Etap ten ma charakter cywilnoprawny i stanowi wyraz woli uczestników ugody, której brak powoduje niemożność wszczęcia drugiego etapu - postępowania administracyjnego. Do czasu złożenia wniosku do organu administracyjnego o zatwierdzenie tej ugody nie ma ona charakteru administracyjnego, lecz jedynie cywilny. Konieczny jest drugi etap z udziałem organu administracji publicznej. Rozpoczyna się on $\mathrm{z}$ momentem złożenia wniosku o zatwierdzenie zawartej ugody ${ }^{37}$ i kończy decyzją zatwierdzającą ugodę lub odmawiającą jej zatwierdzenia ${ }^{38}$. W tym sensie staje się samoistną prawną formą działania administracji.

Ugoda wodnoprawna stanowi szczegółową instytucję konsensualnej zmiany stanu wody na gruncie. Daje więcej możliwości aniżeli ugoda administracyjna zawierana w postępowaniu prowadzonym w trybie art. 234 ust. 3 Prawa wodnego. Ugoda wodnoprawna, jako szczególna forma działania administracji, nie tylko stanowi więc samoistną formę działania administracji, ale wręcz alternatywę procesową dla ogólnej instytucji ugody administracyjnej zawieranej w sprawach zmiany stanu wody na gruncie.

\section{DZIAŁANIA USTAWODAWCY}

VS TYPOWY KATALOG PRAWNYCH FORM DZIALANIA

Czy jest zatem zasadne ustalanie zamkniętego katalogu prawych form działania? Z jednej strony można uznać, że wymaga tego sama doktryna, określając tym samym podstawowy katalog prawnych form działania. Do-

\footnotetext{
${ }^{37}$ Zgodnie z literalnym brzmieniem art. $61 \S 3$ k.p.a.

${ }^{38} \mathrm{~W}$ tym zakresie art. $119 \S 1$ k.p.a.
} 
datkowo, działalność samego prawodawcy przyczynia się do analizy aktualnie uregulowanych prawnych form i podjęcia próby ich klasyfikacji. Jednak, z drugiej strony, ustalenie zamkniętego katalogu prawnych form działania administracji może stanowić utrudnienie i ograniczenie wobec tworzonych nowych form. Jesteśmy zdania, że trudno jest w pełni wyczerpać katalog prawnych form, ponieważ nie jest możliwe, aby przewidzieć, jakie zadania publiczne zostaną uregulowane i tym samym, w jakiej prawnej formie najlepiej byłoby je zrealizować. Trzeba też pamiętać o zmieniających się potrzebach społeczeństwa, które powinny być zaspokajane przez państwo, właśnie przez wykonywanie konkretnych zadań. Wbrew pozorom zadanie, które zostało postawione przed ustawodawcą, jest bardzo trudne. A to dlatego, że powinien on starać się korzystać z prawnych form o charakterze publicznym, które są typowe dla administracji publicznej, pamiętając jednocześnie o efektywnym i prawidłowym wykonaniu zadań publicznych. Można mieć wrażenie, że ustawodawca wraz z nowym zadaniem publicznym tworzy dla niego „nową” prawną formę, która często okazuje się po prostu połączeniem tego, co już jest znane z prawa publicznego, z rozwiązaniami prawnymi, które sprawdzają się w prawie prywatnym. W ten sposób powstają „nowe” prawne formy działania administracji publicznej, które zawierają w sobie cechy prawa publicznego i prywatnego, a zatem stają się tworem hybrydowym. Takie rozwiązanie nie jest zasadne. Potwierdzeniem powyższego stanowiska jest ugoda administracyjna ${ }^{39}$, która niestety w rzeczywistości nie przyczynia się do osiągnięcia takich rezultatów, jakie chciał osiągnąć ustawodawca tworząc tę prawną formę w Kodeksie postępowania administracyjnego.

Działania ustawodawcy, co nawet wskazuje ostatnia nowelizacja Kodeksu postępowania administracyjnego (unormowanie ugody administracyjnej), zmierzają do wprowadzania do administracji publicznej takich instytucji prawnych, które nie posiadają jednoznacznych cech przypisujących je do konkretnej gałęzi prawa. Analiza ugody administracyjnej jako hybrydowej prawnej formy $\mathrm{w}$ administracji publicznej wykazuje, że pomimo zamiaru prawodawcy odformalizowania procedury administracyjnej, co należy uznać za słuszne, nie udało się jednak w pełni osiągnąć tego celu. Wynika to z faktu, że zawarcie takiej ugody obwarowane jest spełnieniem określonych warunków, m.in. może być zawierana pomiędzy określonymi podmiotami. Nie jest

\footnotetext{
${ }^{39}$ Szerzej na temat ugody administracyjnej: P. BieŚ-Srokosz, P. BŁAsIAK, Ugoda administracyjna $w$ świetle nowelizacji Kodeksu postępowania administracyjnego. Refleksje na temat konsensualnej formy działania w administracji publicznej, „Przegląd Prawa Publicznego” 2018, nr 6, s. 96-105.
} 
zatem możliwe przeniesienie wprost na grunt prawa administracyjnego instytucji prawnej z innej gałęzi prawa nie dostosowując jej do niego. Potwierdza to przykład ugody administracyjnej, która nie będzie mieć takich cech i nie będzie wywoływać takich skutków prawnych, jak ugoda w rozumieniu Kodeksu cywilnego. Dzieje się tak dlatego, że administracja publiczna korzysta $\mathrm{z}$ władztwa administracyjnego, a to w konsekwencji przyczynia się do tego, że nigdy nie będzie w stosunkach prawnych na równi z drugą stroną. Stąd też, pomimo występowania w administracji publicznej hybrydowych prawnych form działania, one nadal będą mieć dominujący publiczny charakter prawny, co uważamy za uzasadnione.

\section{WNIOSKI}

Problematyka hybrydowej administracji publicznej jest wynikiem przemian ustrojowych, w szczególności tych, które miały miejsce na początku lat 90. Transformacje z przełomu lat 80. i 90. przyczyniły się do pojawienia nowych zadań publicznych, które miały na celu zaspokoić potrzeby obywateli oraz wpłynąć na rozwój gospodarczy państwa. Dokonywało się to w sytuacji kształtowania się nowych uwarunkowań społecznych, jak i samej roli państwa. Część nowych zadań była także wynikiem dostosowania się do przepisów unijnych, które zobowiązywały państwo polskie do ich realizacji zarówno przed wejściem Polski do Unii Europejskiej, jak i aktualnie jako członka Unii. Niestety, w wielu przypadkach administracja publiczna nie była (i nadal nie jest) wyposażona $\mathrm{w}$ takie instytucje publiczne, w organy czy też narzędzia prawne, które umożliwiałyby jej właściwą realizację nowych zadań publicznych, bądź ich realizację w ogóle. Hybrydowa administracja publiczna to nie tylko zróżnicowane prawne formy administracji publicznej, ale też organy i podmioty administracji publicznej, które mają cechy typowe zarówno dla prawa publicznego, jak i prawa prywatnego. Sam fakt dopuszczenia podmiotów niepublicznych do realizacji zadań publicznych w formach o charakterze prywatnoprawnym może świadczyć, jak zmienia się administracja publiczna idąca $\mathrm{w}$ kierunku mieszanego charakteru prawnego, aniżeli dominującego publicznego charakteru. Administracja publiczna ulega stałym przeobrażeniom, stąd też potrzebne jej są nowe prawne formy działania, odpowiadające jej aktualnym wymaganiom. Należy podkreślić, że nie chodzi tutaj o sztuczne tworzenie nowych instrumentów prawnych, ale 
o uporządkowanie dotychczasowych i dostosowanie ich do zmieniającej się administracji publicznej, a także podjęcie szerszej współpracy z podmiotami niepublicznymi. Oczywiście warto byłoby pochylić się nad tym zagadnieniem w przyszłości, analizując skutki takiej przemiany administracji publicznej. Pojawia się tylko pytanie, czy te skutki będą korzystne dla obywateli i samej administracji publicznej.

$\mathrm{Z}$ drugiej strony, biorąc pod uwagę różnego rodzaju czynniki wpływające na stale rozszerzający się zakres stosowania przez organy administracji publicznej umów cywilnych, należy wskazać przede wszystkim na zjawisko decentralizacji, zmianę stosunków gospodarczych i własnościowych oraz prywatyzację zadań publicznych ${ }^{40}$. Te uwarunkowania przyczyniają się do tego, że administracja publiczna, chcąc wykonywać przypisane jej zadania, korzysta $\mathrm{z}$ form właściwych dla prawa cywilnego, aby zapewnić sobie swobodę i elastyczność działania.

Dokonując podsumowania przeprowadzonych w niniejszym artykule analiz, warto pokusić się o jeszcze jeden wniosek, mianowicie stosowanie prawa administracyjnego i prawa cywilnego $\mathrm{w}$ administracji publicznej uwydatnia funkcjonalne aspekty regulacji prawnej. W konsekwencji to potrzeby społeczne w poszczególnych dziedzinach działalności administracji publicznej wpływają na wybór metody realizacji zadań publicznych, przy czym sam wybór właściwej metody należy już do ustawodawcy ${ }^{41}$. To zaś może się przyczynić - jak zauważa J. Jeżewski - do regulacji tych samych rodzajów spraw prawem administracyjnym i prawem cywilnym lub też odwrotnie ${ }^{42}$.

\section{BIBLIOGRAFIA}

ŹRÓDŁA PRAWA

Ustawa z dnia 14 czerwca 1960 r. - Kodeks postępowania administracyjnego, tj. Dz.U. z 2020 r., poz. 256.

Ustawa z dnia 12 marca 2004 r. o pomocy społecznej, tj. Dz.U. z 2020 r., poz. 1876, 2369.

Ustawa z dnia 20 lipca 2017 r. - Prawo wodne, tj. Dz.U. z 2020 r., poz. 310.

\footnotetext{
${ }^{40}$ B. Dolnicki, R. CYBulsKa, Nowe dwustronne formy dziatania administracji, s. 471.

${ }^{41}$ J. JEŻEWSKI, Administracja pod rzadem prawa cywilnego. $Z$ badań porównawczych nauk prawa administracyjnego, Wrocław: Wydawnictwo Zakład Narodowy im. Ossolińskich 1974, s. 166.

${ }^{42}$ Tamże.
} 


\section{LITERATURA}

BIERNAT Stanisław: Prywatyzacja zadań publicznych. Problematyka prawna, Warszawa: Wydawnictwo Naukowe PWN 1994.

BIEŚ-SROKosz Paulina, BŁASIAK Patryk: Ugoda administracyjna w świetle nowelizacji Kodeksu postępowania administracyjnego. Refleksje na temat konsensualnej formy działania w administracji publicznej, „Przegląd Prawa Publicznego” 2018, nr 6, s. 96-105.

BIEŚ-SROKosz Paulina: Nowe formy organizacyjno-prawne warunkiem dobrego administrowania?, [w:] Aksjologia prawa administracyjnego, red. Jan Zimmermann, Warszawa: Wydawnictwo Wolters Kluwer 2017, s. 307-316.

BŁAŚ Adam: Granice prywatyzacji zadań publicznych w państwie prawa, [w:] Samorząd terytorialny III Rzeczypospolitej. 10 lat doświadczeń, red. Stanisław Michałowski, Lublin: Wydawnictwo UMCS, s. 304-311.

BŁAŚ Adam: Współczesne tendencje przeobrażeń zadań administracji publicznej, [w:] Administracja publiczna, red. Adam Błaś, Jan Boć, Jan Jeżewski, Wrocław: Wydawnictwo Kolonia Limited 2003, s. 148-156.

CWALIŃSKA Joanna M.: Prywatyzacja zadań publicznych - przyczynek do dyskusji, „Przegląd Prawa Publicznego" 2020, nr 3, s. 24-37.

DOLNICKI Bogdan, CYBULSKA Renata: Nowe dwustronne formy działania administracji publicznej. Zagadnienia wybrane, [w:] Koncepcja systemu prawa administracyjnego. Zjazd Katedr Prawa Administracyjnego i Postępowania Administracyjnego, Zakopane 24-27 września 2006 r., red. Jan Zimmermann, Warszawa: Wydawnictwo Oficyna 2007, s. 453-472.

Helios Joanna: Publicyzacja prawa prywatnego - prywatyzacja prawa publicznego w kontekście rozważań nad prawem europejskim, „Przegląd Prawa Administracyjnego” 92 (2013), nr 3502, s.11-36.

JEŻEWSKI Jan: Administracja pod rządem prawa cywilnego. Z badań porównawczych nauk prawa administracyjnego, Wrocław: Wydawnictwo Zakład Narodowy im. Ossolińskich 1974.

KAŁUŻNY Mirosław: Prawo wodne. Komentarz, Warszawa: Wydawnictwo Wolters Kluwer 2016.

KIJOwsKi Dariusz: Umowy w administracji publicznej, [w:] Podmioty administracji publicznej i prawne formy ich działania. Studia i materiały z konferencji jubileuszowej Profesora Ochendowskiego, Toruń: Wydawnictwo Dom Organizatora TNOiK 2005, s. 292-307.

LEMAŃSKA Joanna: Umowa administracyjna a umowa cywilnoprawna, [w:] Instytucje współczesnego prawa administracyjnego, red. Iwona Skrzydło-Niżnik, Piotr Dobosz, Dorota Dąbek, Marcin Smaga, Kraków: Wydawnictwo Uniwersytetu Jagiellońskiego 2001, s. 419-432.

LIPOWICZ Irena: Prawne formy działania administracji publicznej - między stabilizacją a potrzebą przełomu, „Ruch Prawniczy, Ekonomiczny i Socjologiczny” 2016, nr 4, s. 41-55.

LISOWSKI Piotr: Ustrojowe konsekwencje umów w administracji. Wybrane zagadnienia, [w:] Umowy w administracji, red. Jan Boć, Ludmiła Dziewięcka-Bokun, Wrocław: Wydawnictwo Kolonia Limited 2008, s. 89-98.

RABSKA Teresa: Możliwości zmian ustawy samorządowej, „Samorząd Terytorialny” 1994, nr 10, s. $12-27$.

SAFJAN Marek: Pojęcie i systematyka prawa prywatnego, [w:] System prawa prywatnego, t. I: Prawo cywilne - część ogólna, red. Marek Safjan, Warszawa: Wydawnictwo C.H. Beck 2007, s. 29-73. 
SROKOSZ Jacek: Juridification of social life and proces of private law publicisation, [w:] Mutual interaction between contemporary systems and branches of law in European Countries, red. Paulina Bieś-Srokosz, Jacek Srokosz, Ewelina Żelasko-Makowska, Częstochowa: Wydawnictwo S. Podobińskiego 2017, s. 157-170.

STAHL Małgorzata: Zagadnienia ogólne, [w:] Podmioty administrujące. System prawa administracyjnego, red. Roman Hauser, Andrzej Wróbel, t. VI, Warszawa: Wydawnictwo C.H. Beck 2011, s. 1-96.

STARoŚCIAK Jerzy: Prawne formy i metody działania administracji, [w:] System prawa administracyjnego, red. Teresa Rabska, Janusz Łętowski, t. III, Warszawa-Wrocław-Kraków-Gdańsk: Wydawnictwo Zakład Narodowy im. Ossolińskich 1978, s. 42-89.

STEFANIUK Marek: Działanie administracji publicznej w ujęciu nauk administracyjnych, Lublin: Wydawnictwo Uniwersytetu Marie Curie-Skłodowskiej 2009.

SURDYKOwSKA Stanisława Teresa: Prywatyzacja, Warszawa: Wydawnictwo Naukowe PWN 1996.

SzAChUŁOwicz Jan: Prawo wodne. Komentarz, Warszawa: Wydawnictwo Wolters Kluwer 2010.

SzostaK Władysław: Problem „ciężaru państwa”, Kraków: Wydawnictwo Księgarnia Akademicka 1998, s. 241.

WiLCZYŃSKi Przemysław: Podmioty niepubliczne w sferze administracji publicznej, „Państwo i Prawo" 2002, nr 2, s. 49-62.

ZACHARKO Lidia: Prywatyzacja zadań publicznych gminy: studium administracyjnoprawne, Katowice: Wydawnictwo Uniwersytetu Śląskiego 2000.

ZAWADZKI Sylwester: Państwo o orientacji społecznej, Warszawa: Wydawnictwo Naukowe Scholar 1996.

ZiMMERMANN Jan: Prawo administracyjne, Kraków: Wydawnictwo Zakamycze 2005.

ŻURAWIK Artur: Problem publicyzacji prawa prywatnego w kontekście ustrojowym, „Państwo i Prawo" 65 (2010), nr 5, s. 32-41.

\section{HYBRYDOWE PRAWNE FORMY DZIAŁANIA W ADMINISTRACJI PUBLICZNEJ}

Streszczenie

W wyniku przemian ustrojowych, mających miejsce na przełomie lat 80. i 90 . XX wieku, można zauważyć pewnego rodzaju tendencje w działaniach ustawodawcy co do tworzenia nowych zadań publicznych. Zadania te były nie tylko reakcją na zaistniałe zmiany ustrojowe, gospodarcze czy ekonomiczne, ale przede wszystkim na rosnące nowe zapotrzebowania społeczne. Niestety, w administracji publicznej nie funkcjonowały (nadal nie funkcjonują) odpowiednie instytucje i narzędzia prawne czy też organy i podmioty administracji publicznej, za pomocą których jest możliwa realizacja nowych zadań publicznych. Dlatego prawodawca, poszukując optymalnego rozwiązania, zaczął tworzyć hybrydowe prawne formy działania administracji publicznej. To w konsekwencji przyczyniło się do tego, że właśnie te prawne formy stają się coraz częstszą formą regulowaną w polskim prawie aniżeli prawne formy typowe dla prawa administracyjnego, tj. decyzje administracyjne.

Słowa kluczowe: zadania publiczne; prawne formy działania administracji publicznej; hybryda 


\section{HYBRID FORMS OF LEGAL ACTIVITIES IN THE PUBLIC ADMINISTRATION}

\section{S u m m a ry}

As a result of political changes that took place at the turn of the 1980s and 1990s, one can notice some tendencies in the legislator's activities as to the creation of new public tasks. These tasks were not only a reaction to the systemic, economic or economic changes, but above all to the growing new social needs. Unfortunately, in public administration there did not function (still are not functioning) relevant legal institutions and tools, as well as organs and entities of public administration, through which it is possible to implement new public tasks. Therefore, the legislator, seeking the optimal solution, began to create hybrid legal forms of public administration. This, in consequence, contributed to the fact that these legal forms are becoming an increasingly frequent form regulated in Polish law than legal forms typical of administrative law, i.e. administrative decisions.

Keywords: public tasks; the legal forms of public administration; hybrid 